\title{
PEMAHAMAN KONSEP SISWA KELAS VIII PADA MATERI KUBUS DAN BALOK
}

\author{
Kiki Nia Sania Effendi \\ Universitas Singaperbangsa Karawang \\ qqeffendi@gmail.com
}

\begin{abstract}
Abstrak
Artikel ini merupakan hasil penelitian yang bertujuan untuk mengetahui bagaimana kemampuan pemahaman konsep siswa dalam menyelesaikan soal-soal yang berkaitan dengan materi kubus dan balok. Penelitian ini menggunakan pendekatan kuantitatif dengan metode deskriptif. Materi kubus dan balok merupakan salah satu materi matematika yang terdapat pada kompetensi dasar yang harus dikuasai siswa kelas VIII dan erat kaitannya dengan kehidupan sehari-hari. Kubus dan balok merupakan bangun ruang yang sering ditemui oleh siswa dalam kesehariannya, seperti pada saat siswa akan membungkus hadiah dengan kotak yang biasanya berupa kubus atau balok. Teknik pengumpulan data dengan pemberian tes pemahaman konsep bentuk uraian yang sebelumnya dilakukan validasi. Hasil penelitian ini menunjukan nilai hasil tes pemahaman konsep siswa $25,71 \%$ pada kategori tinggi, 54,28\% pada kategori sedang dan $20 \%$ pada kategori rendah.
\end{abstract}

Kata kunci: pemahaman konsep, dan materi kubus dan balok

\begin{abstract}
This article is the result of research aimed to find out how the students understanding of concept in solving the problems associated with concept of cubes and blocks. This research uses quantitative approach with descriptive method. The cubes and blocks is one of the mathematics concepts that exist in the basic competencies that must be mastered by the students of class VIII funds are in everyday life. Cube and block is a space that is often encountered by students in their daily life, such as when students will wrap presents with boxes that are usually cubes or blocks. Precision techniques that previously performed validation. The results of this study showed the students' concept comprehension test of $25.71 \%$ in the high category, $54.28 \%$ in the medium category and $20 \%$ in the low category.
\end{abstract}

Keywords: understanding concepts and materials of cubes and blocks.

\section{PENDAHULUAN}

Pemahaman konsep merupakan kemampuan siswa sebagai hasil belajar yang menunjukan siswa mampu untuk menjelaskan materi yang dipelajari baik sebagian materi maupun materi secara keseluruhan dengan menggunakan bahasanya sendiri. Jika siswa memiliki kemampuan untuk menjelaskan materi dengan bahasanya sendiri tanpa terpaku pada buku, maka dapat dikatakan bahwa siswa tersebut telah memahami konsep suatu materi pelajaran. Menurut Sanjaya (2009) yang di maksud pemahaman konsep adalah kemampuan siswa yang berupa penguasaan sejumlah materi pelajaran, dimana siswa tidak sekedar mengetahui atau mengingat sejumlah konsep yang dipelajari, tetapi mampu mengungkapan kembali dalam bentuk lain yang mudah dimengerti, memberikan interprestasi data dan mampu mengaplikasikan konsep yang sesuai dengan struktur kognitif yang dimilikinya.

National Council of Teacher Mathematic (NCTM, 2000) menetapkan 5 kemampuan proses yang harus dikuasai siswa melalui pembelajaran matematika, yaitu : (1) pemecahan masalah (problem solving); (2) penalaran dan pembuktian (reasoning and proof); (3) koneksi (connection); (4) komunikasi (communication); serta (5) representasi (representation). Kelima kemampuan tersebut akan berkembang apabila siswa tersebut memiliki kemampuan pemahaman konsep melalui pembelajaran matematika. Dengan kata lain, kemampuan pemahaman konsep merupakan kemampuan dasar yang harus dimiliki siswa dalam pembelajaran matematika. Dalam NCTM (2000) disebutkan bahwa kemampuan pemahaman merupakan aspek yang sangat penting dalam prinsip pembelajaran matematika. 
Menurut Depdiknas (2006), Salah satu tujuan Kurikulum KTSP pelajaran matematika yaitu agar siswa memiliki kemampuan memahami konsep matematika, menjelaskan keterkaitan antarkonsep dan mengaplikasikan konsep atau algoritma, secara luwes, akurat, efisien, dan tepat, dalam pemecahan masalah. Zulkardi (2003:7) bahwa "mata pelajaran matematika menekankan pada konsep". Seseorang yang memiliki pemahaman terhadap banyak konsep maka kemungkinan besar dapat memecahkan masalah dengan lebih baik, sebab untuk memecahkan masalah perlu aturan-aturan yang berdasarkan pada konsepkonsep yang dimiliki.

Kemampuan pemahaman konsep berperan besar dalam menentukan hasil belajar siswa dalam pembelajaran matematika. Dengan dimilikinya kemampuan ini oleh siswa maka akan memudahkan dalam mempelajari dan menyelesaikan masalah matematika. Dalam kegiatan pembelajaran matematika hendaknya menekankan pada kegiatan yang dapat meningkatkan pemahaman konsep agar siswa memiliki kemampuan dasar yang baik untuk mencapai kemampuan matematis lainnya seperti penalaran, komunikasi, koneksi dan pemecahan masalah. Proses pembelajaran di dalam kelas dengan mengarahkan anak pada kemampuan cara menggunakan rumus, menghafal rumus, matematika hanya untuk mengerjakan soal, jarang diajarkan untuk menganalisis dan menggunakan matematika dalam kehidupan sehari-hari kurang mendorong anak untuk mengembangkan kemampuan berpikirnya (Kesumawati, 2008). Jbeili (2012: 1) menyatakan bahwa pemahaman konsep merujuk kepada kemampuan siswa untuk menghubungkan gagasan baru dalam matematika dengan gagasan yang mereka ketahui, untuk menggambarkan situasi matematika dalam cara yang berbeda dan untuk menentukan perbuatan antara penggambaran ini. Menurut Sanjaya (2009) indikator pemahaman konsep diantaranya: (a) mampu menerangkan secara verbal mengenai apa yang telah dicapainya; (b) mampu menyajikan situasi matematika kedalam berbagai cara serta mengetahui perbedaan; (c) mampu mengklasifikasikan objek-objek berdasarkan dipenuhi atau tidaknya persyaratan yang membentuk konsep tersebut; (d) mampu menerapkan hubungan antara konsep dan prosedur; mampu menberikan contoh dan kontra dari konsep yang dipelajari; (e) mampu menerapkan konsep secara algoritma; (f) mampu mengembangkan konsep yang telah dipelajari.

Siswa dikatakan memiliki kemampuan pemahaman konsep dalam pembelajaran matematika jika indikator pada pemahaman konsep terpenuhi. Sebagai contoh pembelajaran pada materi bangun datar segitiga, jika siswa telah menguasai konsep segitiga maka siswa tersebut mampu menjelaskan kembali dengan kalimatnya sendiri definisi maupun sifat dari segitiga. Selanjutnya, siswa tersebut mampu mengklasifikasi segitiga berdasarkan jenisnya sehingga siswa mampu memberi contoh-contoh benda yang berbentuk segitiga serta menentukan jenisnya. Setelah itu, siswa mampu menyelesaikan soal rutin dengan konsep luas dan keliling segitiga serta permasalahan sehari-hari yang ada kaitannya dengan konsep segitiga sehingga konsep tersebut dapat dipahami dan dikembangkan dengan penyelesain masalah yang dihadapi dalam keseharian mereka.

Dalam keseharian kita tidak sedikit menemukan benda-benda yang berbentuk kubus dan balok. Saat kita akan memeberi seseorang hadiah yang dimasukan pada sebuah kotak yang biasanya berbentuk kubus maupun balok. Tentunya kotak tersebut akan terlihat lebih indah ketika dibalut dengan kertas kado. Pada saat itulah disadari ataupun tidak kita akan memperkirakan luas dari kertas kado tersebut akan menutupi permukaan kotak dari hadiah tersebut. Selain fenomena tersebut masih banyak lagi fenomena yang berkaitan dengan kubus dan balok yang sering kita temui dalam kehidupan sehari-hari. Berdasarkan uraian di atas menunjukan peranan penting pemahaman konsep dalam pembelajaran matematika maka peneliti tertarik untuk menganalisis pemahaman konsep siswa dalam menyelesaikan masalah yang berkaitan dengan kubus dan balok 


\section{METODE PENELITIAN}

Penelitian ini merupakan penelitian kuantitatif dan menggunakan metode deskriptif. penelitian yang berlandaskan pada filsafat positivisme, digunakan untuk meneliti pada populasi atau sampel tertentu. Teknik pengambilan sampel pada umumnya dilakukan secara random, pengumpulan data menggunakan instrumen penelitian, analisis data bersifat kuantitatif/statistik dengan tujuan untuk menguji hipotesis yang telah ditetapkan (Sugiyono, 2012: 7). Penelitian deskriptif (descriptive research) menurut Furchan (2004: 54) adalah suatu metode penelitian yang ditujukan untuk menggambarkan fenomena-fenomena yang ada, yang berlangsung pada saat ini atau saat yang lampau. Berdasarkan teori tersebut, penelitian deskriptif kuantitatif, merupakan data yang diperoleh dari sampel populasi penelitian dianalisis sesuai dengan metode statistik yang digunakan. Penelitian deskriptif dalam penelitian ini dimaksudkan untuk mendapatkan gambaran dan keterangan-keterangan mengenai pemahaman konsep siswa dari hasil jawaban siswa. Subjek dalam penelitian ini adalah siswa kelas VIII sebanyak 35 siswa disalah satu sekolah di kabupaten karawang. Data yang diperoleh berupa hasil tes pemahaman konsep berupa tes uraian yang soal-soalnya berkaitan dengan materi kubus dan balok. Selanjutnya, data diolah dan dianalisis berdasarkan nilai yang diperoleh siswa tersebut. Dalam menentukan kategori dari hasil tes pemahaman konsep siswa dalam soal-soal yang berkaitan dengan kubus dan balok melalui cara kategorisasi yang didasari oleh nilai rata-rata dan standar deviasi. Menurut Arikunto (2010) nilai rata-rata dan standar deviasi dari data penelitian dapat menentukan kategori tinggi, sedang dan rendah. Siswa yang berada pada kategori tinggi siswa yang memperoleh nilai lebih dari nilai rata-rata yang dijumlahkan dengan standar deviasi. Siswa yang berada pada kategori rendah siswa yang memperoleh nilai kurang dari selisih dari nilai rata-rata dengan standar deviasi. Sedangkan siswa yang berada pada kategori sedang siswa yang memperoleh nilai yang ada diantara nilai dikategori tinggi dan rendah (Arikunto, 2010).

\section{HASIL DAN PEMBAHASAN}

Hasil penelitian ini merupakan nilai yang diperoleh siswa pada tes kemampuan pemahaman konsep dalam menyelesaikan soal-soal yang berkaitan dengan kubus dan balok. Adapun hasil nya sebagai berikut:

\section{Tabel 1}

Hasil Tes Pemahaman Konsep

\begin{tabular}{cccc}
\hline Jumlah Siswa & $\begin{array}{c}\text { Nilai } \\
\text { Maksimum }\end{array}$ & $\begin{array}{c}\text { Nilai } \\
\text { Minimum }\end{array}$ & Rata-rata \\
\hline 35 & 40 & 0 & 20,57 \\
\hline
\end{tabular}

Berdasarkan tabel 1 menunjukan nilai siswa belum mencapai nilai Kriteria Ketuntasan Minimal (KKM) sekolah tersebut termasuk siswa yang memperoleh nilai tertinggi yang hanya mencapai nilai 40 . Pada tes ini, nilai minimum siswa adalah 0 dan rata-rata nilai pada kelas ini adalah 20,57. Jika ditinjau dari masing-masing indikatorpun pada hasil nilai tersebut pada interpretasi sangat kurang karena nilai yang diperoleh seluruh siswa dari setiap indikator pemahaman konsep tidak ada yang memperoleh nilai maksimum. Dengan demikian persentasenya adalah $0 \%$ dari seluruh indikator pemahaman konsep. Dari hasil tersebut dapat dikatakan bahwa pemahaman konsep siswa pada penyelesaian soal-soal materi kubus dan balok masih rendah yang artinya siswa pada kelas tersebut belum memahami konsep kubus dan balok. Hal tersebut bertolak belakang dengan pendapat Nasution (2006: 161) yang mengatakan bahwa pemahaman konsep adalah kemampuan individu untuk memahami suatu konsep. Selanjutnya, untuk mengetahui 
kategori tinggi, sedang, dan rendah pemahaman konsep siswa pada kelas ini sebagai subjek penelitian menggunakan cara yang dikemukakan oleh Arikunto (2010) nilai rata-rata dan standar deviasi dari data penelitian menjadi dasar dalam kategorisasi.

Tabel 2

Tingkat Pemahaman Konsep Siswa

\begin{tabular}{cccc}
\hline Kategori & Kriteria Nilai & Jumlah Siswa & Persentase \\
\hline Tinggi & $>26,67$ & 9 & 25,71 \\
Sedang & $13,33 \leq$ Nilai $\leq 26,67$ & 19 & 54,28 \\
Rendah & $<13,33$ & 7 & 20 \\
\hline
\end{tabular}

Tabel 2 menunjukan kategori pemahaman konsep siswa dalam menyelesaikan soalsoal yang berkaitan dengan kubus dan balok. Pada kategori tinggi sebesar 25,71\% sebanyak 9 orang siswa dengan perolehan nilai siswa yang lebih dari 26,67 dan kategori rendah 20\% sebanyak 7 orang siswa dengan perolehan nilai siswa yang kurang dari13,33. Persentase terbesar pada kategori sedang dengan perolehan persentase sebesar 54,28\% terdiri dari 19 orang siswa dengan perolehan nilai siswa diantara 13,33 dan 26,67. Kategorisasi tersebut menujukan bahwa siswa pada kategori tinggi dikelas tersebut masih belum menguasai pemahaman konsep materi kubus dan balok karena berdasarkan nilai maksimum yang diperoleh hanya mencapai nilai 40 yang nilai dari masing-masing indikator tidak mencapai nilai maksimal. Hal tersebut menunjukan kategori tersebut hanya berlaku pada kelas ini sebagai subjek penelitian ini. Perbandingan persentase tingkat pemahaman konsep siswa pada materi kubus dan balok terlihat pada gambar diagram dibawah ini:

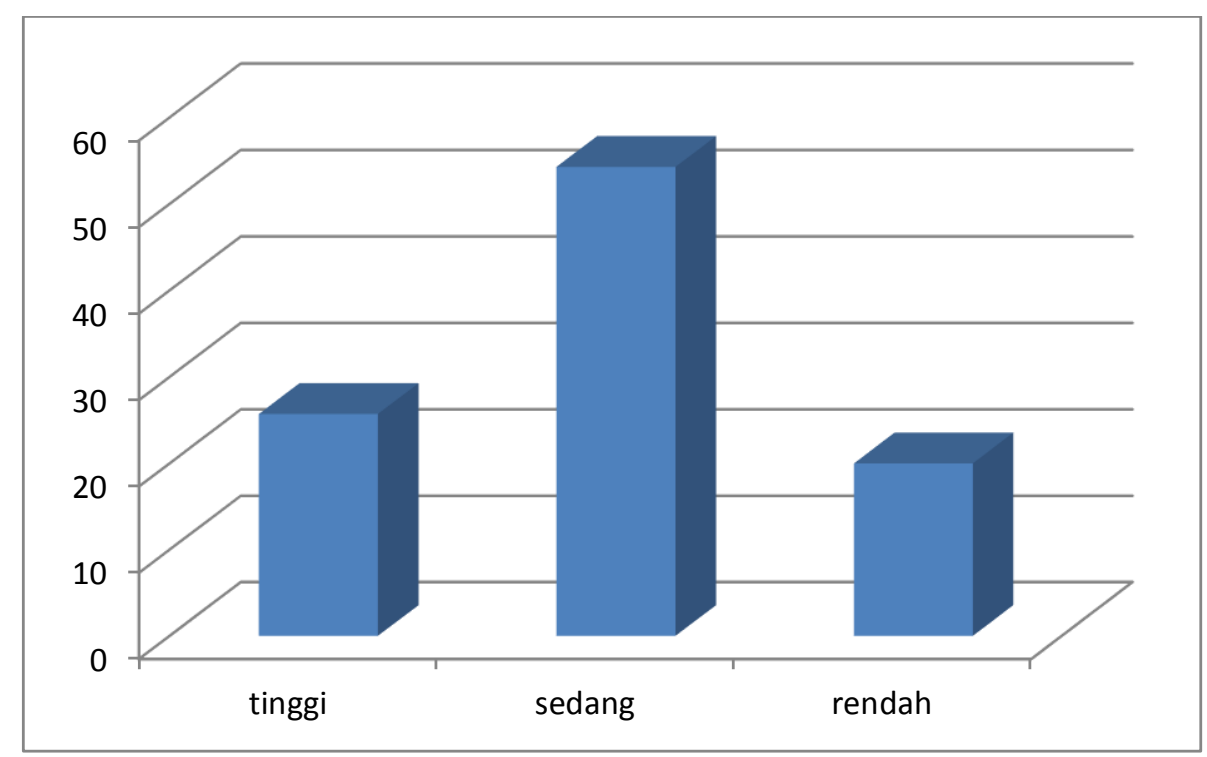

Gambar 1. Perbandingan persentase tingkat pemahaman konsep siswa pada materi kubus dan balok

Berdasarkan uraian sebelumnya mengenai hasil penelitian dari nilai masing-masing indikator yang masih dikatakan sangat kurang karena tak satu siswapun dapat nilai maksimal pada jawaban mereka disetiap soal tes tersebut. Sejalan dengan fakta yang ditemukan di SMP 3 Batusangkar oleh Murizal, Yaman, dan Yerizon (2012) banyak siswa yang kesulitan dalam memahami konsep matematika. Padahal kemampuan pemahaman merupakan aspek yang sangat penting dalam prinsip pembelajaran matematika (NCTM, 2000). Meski 
demikian, siswa tersebut masih memperoleh nilai dari masing-masing soal yang artinya setiap indikator dari pemahaman konsep belum terpenuhi secara maksimal. Indikator pemahaman konsep digunakan dalam penelitian adalah indikator pemahaman konsep dalam pembelajaran matematika yang tercantum dalam KTSP (Depdiknas, 2006) yaitu: menyatakan ulang konsep yang telah dipelajari; mengklasifikasikan objek - objek berdasarkan konsep matematika; memberikan contoh dan bukan contoh dari konsep yang telah dipelajari; menyatakan konsep dalam berbagai representasi; mengembangkan syarat perlu atau syarat cukup suatu konsep; mengaplikasikan konsep atau alogaritma pemecahan masalah. Indikator-indikator tersebut belum tercerminkan telah dikuasai oleh siswa yang terlihat pada jawaban siswa. Adapun soal-soal yang diberikan adalah sebagai berikut:

1. Gambarkanlah sebuah balok PQRS.TUVW, lalu sebutkanlah sifat - sifat dari bangun ruang tersebut!

2. Dari gambar kubus PQRS.TUVW di bawah ini tentukan mana yang dimaksudengan:

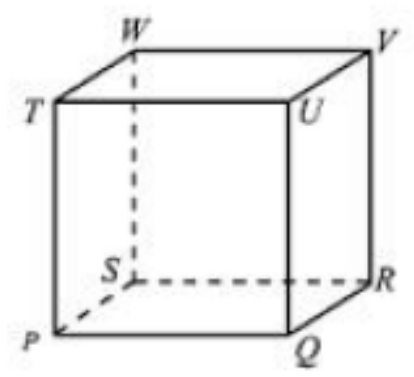
a. Sisi
b. Rusuk
c. Titik sudut
d. Diagonal bidang
e. Diagonal ruang
f. Bidang diagonal

3. Perhatikan unsur - unsur berikut ini:

a. Sisi/bidang, rusuk, titik sudut, diagonal bidang, diagonal ruang dan bidang diagonal.

b. Rusuk, titik sudut, diagonal bidang, volume, rusuk dan titik sudut.

c. Luas permukaan, volume, rusuk, titik sudut, diagonal bidang dan diagonal ruang. Bagian manakah dari unsur - unsur tersebut yang merupakan unsur - unsur kubus? Jelaskan!

4. Dari gambar dibawah ini ubahlah kedalam bentuk jaring - jaring pada bangun ruang tersebut!
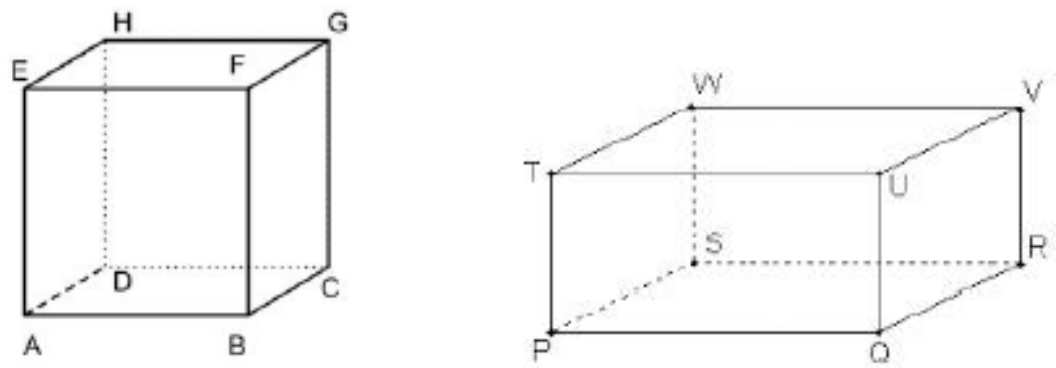

5. Reza mempunyai sebuah akuarium berbentuk balok dengan panjang $10 \mathrm{~cm}$, lebar 5 $\mathrm{cm}$, dan tinggi $7 \mathrm{~cm}$. Jika akuarium terisi penuh oleh air, maka bagaimana cara menghitung volume air tersebut?

6. Pak Maman membuat sebuah bak mandi yang berbentuk kubus dengan ukuran sisinya $120 \mathrm{~cm}$. Jika Pak Maman mengisi bak tersebut dengan air sampai penuh. Maka berapa liter air kah yang diperlukan oleh pak Maman untuk memenuhi bak mandinya?

Selanjutnya, gambar dari jawaban siswa pada penyelesaian soal-soal yang berkaitan dengan materi kubus dan balok sebagai berikut: 


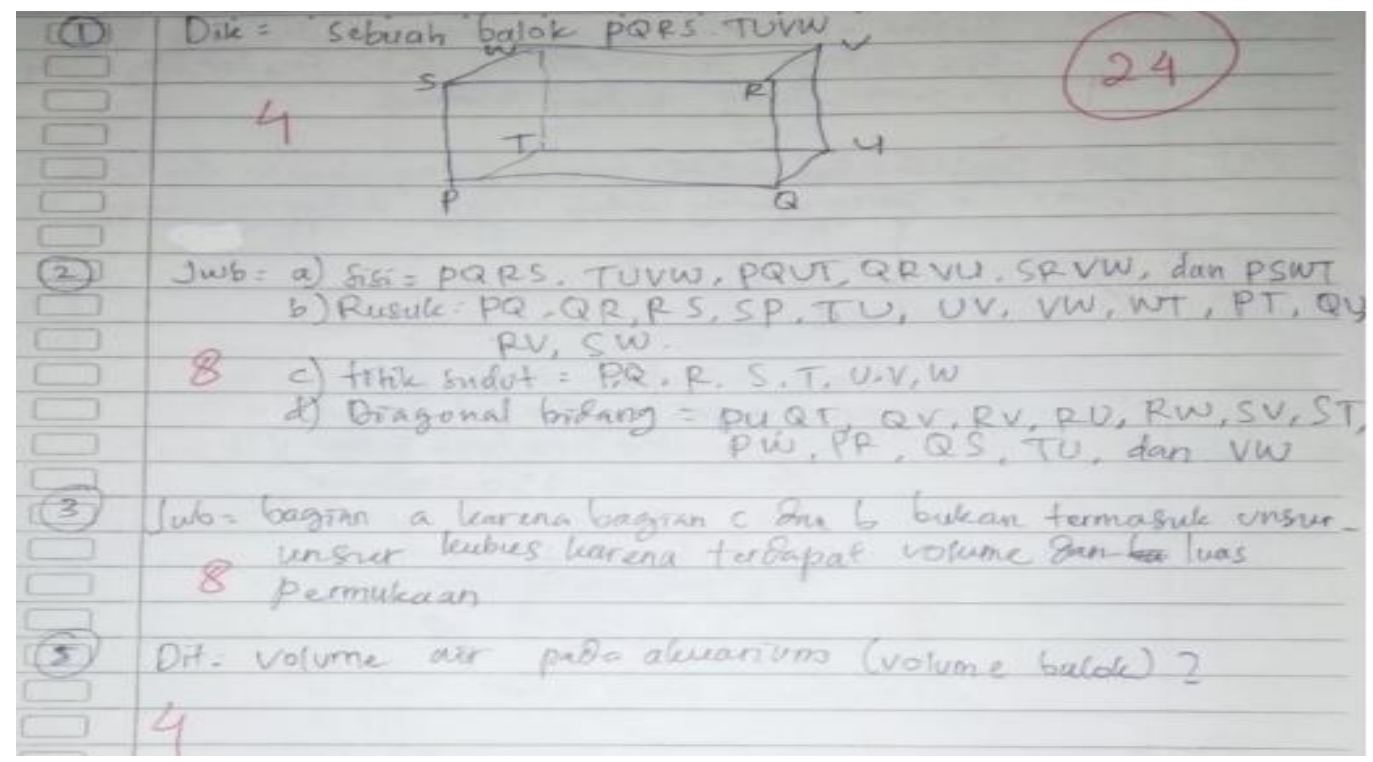

Gambar 2. Jawaban Siswa.

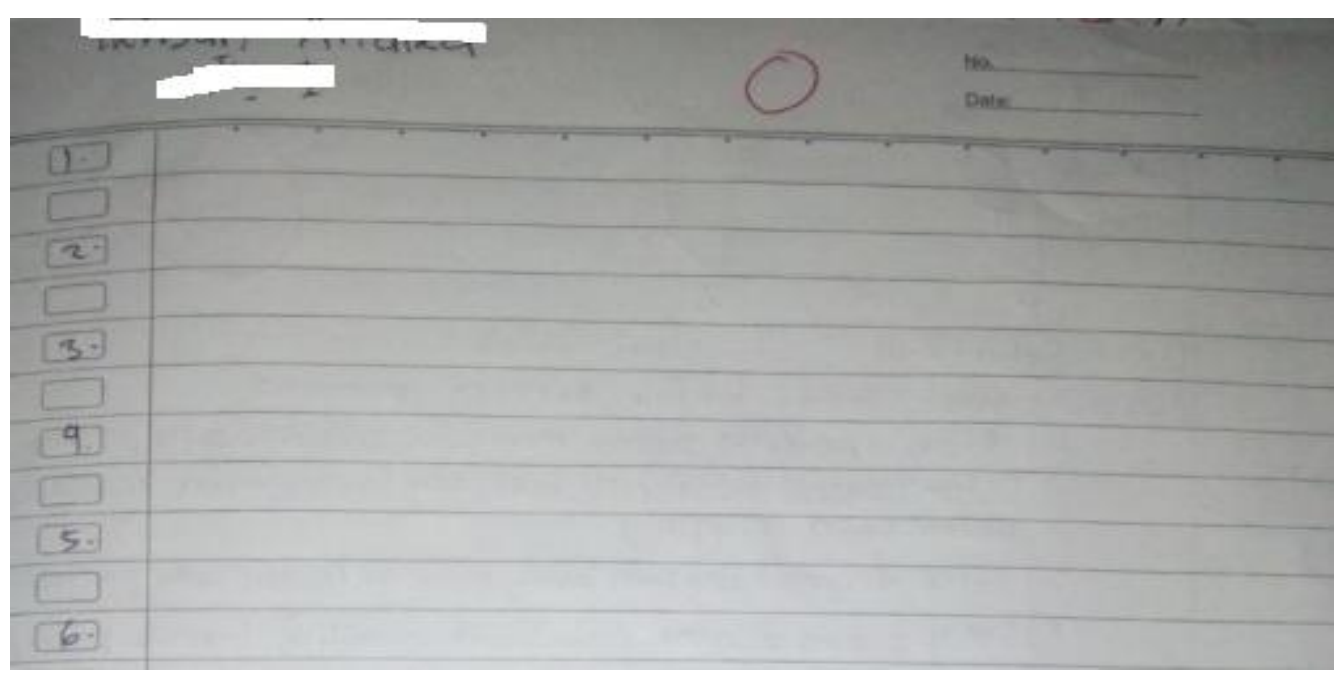

Gambar 3. Jawaban Siswa.

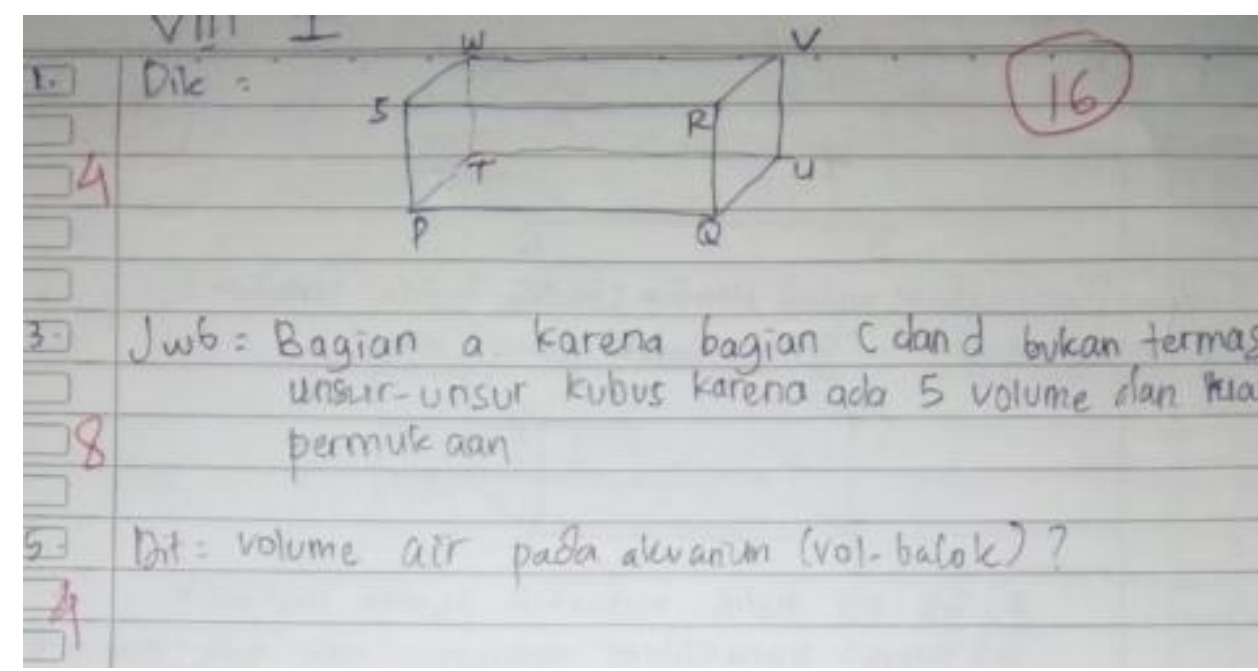

Gambar 4. Jawaban Siswa. 
Jawaban siswa belum mencerminkan indikator kemampuan menyatakan ulang konsep yang telah dipelajari terlihat ada beberapa siswa yang hanya menulis ulang soal yang diberikan, menggambarkan saja balok tanpa memberi huruf pada setiap titik balok tersebut hingga menuliskan dua buah sifat dari balok. Hal yang sama terlihat kembali yaitu menulis ulang soal pada indikator mengklasifikasikan objek - objek berdasarkan konsep matematika. selain itu, adapula siswa yang mampu menuliskan apa yang ia ketahui dari soal tersebut hingga ia mampu menuliskan beberapa sisi, rusuk dan titik sudut dari sebuah balok. Pada indikator memberikan contoh dan bukan contoh dari konsep yang telah dipelajari terlihat siswa mampu memberikan contoh dari beberapa unsur pada sebuah kubus tanpa memberikan penjelasan. Indikator menyatakan konsep dalam berbagai representasi belum terlihat dikuasai oleh siswa karena jawaban siswa masih kesulitan dalam menggambarkan jaring-jaring kubus dan balok. Pada indikator mengembangkan syarat perlu atau syarat cukup suatu konsep pun belum dikuasai siswa karena jawaban siswa menunjukan siswa masih kesulitan untuk menentukan rumus yang digunakan untuk menghitung volume sebuah benda yang berbentuk balok. Selanjutnya, indikator mengaplikasikan konsep atau alogaritma pemecahan masalah masih belum terpenuhi oleh siswa, terlihat dari jawaban siswa yang kesulitan menentukan yang ia ketahui dari permasalahan tersebut sehingga tidak mampu memberi solusi dalam permasalahan seberapa liter air yang diperlukan untuk mengisi bak mandi hingga penuh. Jawaban siswa dari seluruh indikator terdapat beberapa siswa yang hanya menulis nomor soal tanpa adanya jawaban sama sekali.

\section{KESIMPULAN}

Berdasarkan hasil penelitian dan pembahasan yang diuraikan sebelumnya mengenai pemahaman konsep siswa kelas VIII pada materi kubus dan balok menunjukan seluruh indikator pemahaman konsep belum terpenuhi secara maksimal oleh seluruh siswa. Tingkat pemahaman konsep dari 35 siswa di kelas VIII berdasarkan nilai yang diperoleh siswa secara keseluruhan terdapat 9 orang siswa pada kategori tinggi dengan persentase 25,71\%, 19 orang siswa pada kategori sedang dengan persentase $54,28 \%$ dan 7 orang siswa pada kategori rendah dengan persentase $20 \%$.

\section{SARAN}

Berdasarkan temuan yang diperoleh dari penelitian ini saran yang dapat peneliti sampaikan adalah :

a. Hasil penelitian ini diharapkan dapat membantu siswa dalam menyadari kekurangan dan kelebihan pemahaman konsep mereka dalam pembelajaran matematika sehingga siswa akan berupaya untuk meningkatkan kemampuannya.

b. Hasil penelitian ini diharapkan dapat membantu guru dalam memahami kemampuan pemahaman konsep yang dimiliki siswa sehingga guru dapat merencanakan suatu kegiatan pembelajaran matematika yang bermakna dan meningkatkan kemampuan pemahaman konsep siswa.

c. Hasil penelitian ini diharapkan dapat menjadi ide bagi penelitian lainnya untuk melaksanakan penelitian lanjutan yang berpotensi untuk meningkatkan pemahaman konsep siswa dalam pembelajaran matematika.

\section{REFERENSI}

Arikunto, S. 2010. Prosedur Penelitian Suatu Pendekatan dan Praktik. Jakarta: PT Rineka Cipta. 
Depdiknas. 2006. Kurikulum Tingkat Satuan Pendidikan. Jakarta: Departemen Pendidikan Nasional.

Furchan, A . 2004. Pengantar Penelitian dalam Pendidikan. Yogyakarta: Pustaka Pelajar. Jbeili. 2012. The Effect of Coverative Learning with Metacognitive Scaffolding on Mathematis Conceptual Understanding and Procedural Fluency. In International Journal for Research in Education (IJRE) No. 32. [online] Tersedia: http://www.fedu.uaeu.ac.ae/journal/docs/pdf/pdf32 [15 April 2017].

Kesumawati, N. 2008. Pemahaman Konsep dalam Pembelajaran Matematika. Prosiding Seminar Nasional Matematika dan Pendidikan Matematika. [online] Tersedia:http://eprints.uny.ac.id/6928/1/P18\%20Pendidikan\%28Nila\%20K\%29.pdf . [15 April 2017].

Murizal, Yaman, dan Yerizon. 2012. Pemahaman Konsep dan Quantum Learning. Jurnal Pendidikan Matematika Vol. 1 No. 1. [online] Tersedia: http://ejournal.unp.ac.id/students/index.php/pmat/article/view/1138/830 [ $\quad 19$ Desember 2017].

Nasution, S. 2006. Berbagai Pendekatan dalam Proses Belajar \& Mengajar. Jakarta: Bumi Aksara.

NCTM.(2000). Principle and Standards for School Mathematic. Virginia: NCTM.

Sanjaya, W. 2009. Strategi Pembelajaran Berorientasi Standar Proses Pendidikan. Jakarta: Prenada.

Sugiyono. 2012. Metode Penelitian Kuantitatif Kualitatif dan R\&D. Bandung: Alfabeta.

Zulkardi. 2003. Pendidikan Matematika di Indonesia: Beberapa Permasalahan dan Upaya Penyelesaiannya. Palembang: Unsri. 